\title{
Analisis Respon Pertumbuhan Ekonomi Indonesia Akibat External Shock Amerika Serikat dan China
}

\author{
Alvin Sugeng Prasetyo ${ }^{1 *}$, Mochamad Devis Susandika ${ }^{2}$ \\ ${ }^{1}$ Universitas Trunojoyo Madura, Kabupaten Bangkalan, Jawa Timur, Indonesia. \\ ${ }^{2}$ Universitas Airlangga, Surabaya, Jawa Timur, Indonesia \\ Email: alvin.prasetyo@trunojoyo.ac.id
}

\begin{abstract}
Abstrak
Tujuan penelitian ini yaitu menguji dan menganalisis respon pertumbuhan ekonomi Indonesia akibat shock eksternal dari Amerika Serikat dan China. Metode yang digunakan yaitu VECM, karena stasioner pada I(1) dan terdapat kointegrasi. Data yang digunakan periode 2004:I-2020:I. Hasil estimasi menunjukkan bahwa Hasil estimasi VECM menunjukkan bahwa ketidakpastian kebijakan ekonomi China dan kontibusi pertumbuhan ekonomi China lebih berpengaruh besar dibandingkan Amerika Serikat terhadap pertumbuhan ekonomi Indonesia. Shock kurs rupiah terhadap dolar Amerika Serikat lebih baik dibandingkan dengan kurs rupiah terhadap RMB. Shock perubahan harga minyak direspon negatif oleh perubahan pertumbuhan ekonomi Indonesia. Dalam jangka panjang juga tidak terlihat tanda-tanda pergerakan respon perubahan pertumbuhan ekonomi Indonesia menuju keseimbangan (convergence).
\end{abstract}

Kata Kunci: pertumbuhan ekonomi Indonesia, shock eksternal, China, Amerika Serikat, VECM

\begin{abstract}
The purpose of this study is to examine and analyze the response to Indonesia's economic growth caused by external shocks from the United States and China. The method used is VECM, because it is stationary at I (1) and there is cointegration. The estimation results show that the uncertainty of China's economic policies and the contribution of China's economic growth has a greater effect than the United States on Indonesia's economic growth. The shock of the rupiah exchange rate against the US dollar was better than the rupiah exchange rate against the RMB. The shock of changes in oil prices was responded negatively by changes in Indonesia's economic growth. In the long term, there are no signs of a movement in response to changes in Indonesia's economic growth towards equilibrium (convergence).
\end{abstract}

Keywords: Indonesia's economic growth, external shock, China, United States, VECM

\section{Pendahuluan}

Pertumbuhan ekonomi merupakan variabel makroekonomi yang sangat menarik dilakukan penelitian empiris berkelanjutan. Hal ini karena pertumbuhan ekonomi menjadi indikator kinerja ekonomi suatu negara. Pertumbuhan ekonomi yang rentan terhadap guncangan, baik yang bersumber dari dalam negeri maupun dari luar negeri, maka berdampak pada ketidakstabilan kinerja ekonomi suatu negara, misalnya mengalami resesi, sehingga perlu mengimplementasikan langkah-langkah yang tepat untuk memperkuat daya tahan perekonomian domestik (Dutu, 2016).

Indonesia merupakan salah satu negara yang terus melakukan stabilitas pertumbuhan ekonomi. Pertumbuhan ekonomi yang tidak terjaga berdampak negatif terhadap stabilitas makroekonomi Indonesia. Hal ini meningkatkan risiko sistemik, mengurangi investasi, dan menurunkan daya saing perdagangan internasional (Kala et al., 2018). Faktor yang mengganggu kinerja pertumbuhan ekonomi Indonesia salah satunya dari eksternal. Guncangan ekonomi yang berasal dari luar (external shock) yang disebabkan oleh perubahan penawaran agregat (supply shock) (Agénor et al., 2018). Faktor eksternal yang digunakan dalam studi ini bersumber dari Amerika Serikat dan China. Amerika Serikat dipilih karena semua kebijakan ekonomi berdampak signifikan terhadap spekulasi dan stabilitas ekonomi global, sedangkan China dipilih karena kekuatan ekonomi dalam beberapa dekade terakhir dapat menjadi rival Amerika Serikat.

Ekonomi Amerika Serikat dan China telah menguasai ekonomi global melalui hubungan keuangan dan perdagangan, sehingga kedua negara tersebut dikatakan sebagai large open economy. Ekonomi Amerika Serikat dan China jika sedang memburuk atau membaik, maka mendorong transmisi shock ke negara small open economy, termasuk Indonesia, artinya shock yang ditimbulkan tersebut bisa berdampak pada pertumbuhan ekonomi Indonesia. Guncangan eksternal yang disebabkan karena adverse supply shock tidak diimbangi dengan peningkatan aggregate demand, menyebabkan stagnasi atau kontraksi pertumbuhan ekonomi di Indonesia, maka menjaga pertumbuhan ekonomi Indonesia menjadi tidak mudah. Hal ini sejalan dengan pendapat dari Allegret \& Benkhodja, (2015), shock berkaitan dengan penyebab ekspansi dan kontraksi, sehingga indikator makroekonomi yang terkena shock mengalami fluktuatif.

Pertumbuhan ekonomi Amerika Serikat dan China menjadi dapat menjadi faktor penentu kinerja pertumbuhan ekonomi Indonesia. Hal ini dikaitkan karena hubungan bilateral kedua negara tersebut dengan Indonesia mengalami peningkatan. Perlambatan pertumbuhan

\footnotetext{
${ }^{*}$ Corresponding author 
ekonomi di kedua negara tersebut dapat menganggu kinerja ekspor Indonesia, sehingga neraca perdagangan terancam mengalami defisit dan berdampak negatif pada pertumbuhan ekonomi Indonesia (Dungey \& Vehbi, 2015). Shock dari ketidakpastian kebijakan ekonomi Amerika Serikat dan China dapat mempengaruhi pertumbuhan ekonomi Indonesia. Ketidapastian kebijakan ekonomi kedua negara tersebut menjadi topik yang intensif dibahas terutama bermula ketika Amerika Serikat (AS) mengalami krisis subprime mortgage yang terjadi pada tahun 2008 lalu dan ditambah dengan kedua negara melakukan perang dagang, sehingga perekonomian kedua negara melemah (Istiak \& Serletis, 2018). Ketidakpastian kebijakan ekonomi kedua negara tersebut memberikan makna bahwa ketidakmampuan suatu lembaga di kedua negara tersebut dalam memprediksi kebijakan ekonomi masa depan serta tidak mampu menerima konsekuensi dari kebijakan yang yang diambilnya (Liu et al., 2020). Hal ini karena lembaga di kedua negara tersebut sering menghadapi ketidakpastian tentang waktu, konten, dan potensi efek keputusan kebijakan.

Penggunaan indeks ketidakpastian kebijakan ekonomi dapat membantu investor atau pengambil kebijakan untuk lebih bijak dalam mengambil keputusan di berbagai bidang. Dampak peningkatan ketidakpastian kebijakan ekonomi Amerika Serikat dan China direspon negatif oleh pertumbuhan ekonomi Indonesia, tetapi sebaliknya penurunan ketidakpastian kebijakan ekonomi Amerika Serikat dan China akan direspon positif oleh perubahan PDB Indonesia. Hasil penelitian tersebut juga relevan dengan pernyataan dari Bhagat et al., (2013) bahwa respons impuls akan mengkonfirmasi positif jika ketidakpastian kebijakan ekonomi menurun, maka mengindikasikan aktivitas ekonomi yang positif, namun sebaliknya guncangan ketidakpastian kebijakan yang semakin tinggi menyebabkan penurunan aktivitas ekonomi, sehingga respons impuls akan mengkonfirmasi negatif.

Pertumbuhan ekonomi Indonesia juga dapat terguncang akibat shock harga minyak dunia. Minyak dibutuhkan sekali oleh Indonesia, karena sebagai input produksi di sektor industri, sebagai bahan bakar sektor transportasi, dan dibutuhkan di tingkat rumah tangga (Haseeb et al., 2021). Indonesia dahulu pernah menjadi salah satu negara pengekspor minyak bumi dan tergabung menjadi anggota OPEC, tetapi sejak tahun 2004 sampai saat ini berubah menjadi negara pengimpor minyak. Hal ini karena permintaan minyak lebih besar dibandingkan penawaran minyak, sehingga untuk menutupi kebutuhan minyak tersebut, maka Indonesia melakukan impor minyak (Artami \& Hara, 2018).

Shock harganya minyak dunia terhadap pertumbuhan ekonomi Indonesia dapat melalui supply side shock effect. Efek shock sisi penawaran menjelaskan bahwa kenaikan harga minyak dunia menyebabkan penggunaan input produksi minyak menurun, sebab perusahaan memilih untuk melakukan penghematan (Nizar, 2012). Hal ini dapat menghambat produktivitas perusahaan, sehingga output mengalami penurunan. Kenaikan harga minyak dunia merupakan shock yang dapat menimbulkan peningkatan marginal cost perusahaan, sehingga perusahaan mengurangi produksi. Kondisi tersebut memperlambat pertumbuhan ekonomi. Jika kenaikan harga minyak dunia berkelanjutan, maka dapat berakibat resesi ekonomi.

Kurs rupiah/USD dan rupiah/RMB berpengaruh terhadap pertumbuhan ekonomi di Indonesia. Shock kurs dapat direspon positif oleh pertumbuhan ekonomi (Kala et al., 2018). Depresiasi kurs rupiah/USD dan rupiah/RMB dapat mendorong pertumbuhan ekonomi, karena depresiasi kurs dapat mendorong ekspor lebih tinggi sehingga ekspor neto Indonesia mengalami surplus dan berdampak positif terhadap pertumbuhan ekonomi (Murtala et al., 2017). Kebijakan moneter menggunakan instrumen suku bunga untuk menstabilkan kurs. Otoritas moneter dalam hal ini adalah Bank Indonesia dapat mengimplementasikan tight monetary policy untuk menstabilkan pergerakan kurs. Tight monetary policy dilakukan dengan memposisikan interest rate acuan lebih besar dibandingkan periode sebelumnya. Suku bunga ditingkatkan oleh dewan gubernur tersebut bertujuan untuk meningkatkan investasi masuk ke Indonesia sehingga mendorong pertumbuhan ekonomi lebih tinggi.

Studi tentang ketidakpastian kebijakan ekonomi terhadap pertumbuhan ekonomi dilakukan oleh (Liu et al., 2020). Hasil estimasi tersebut menunjukkan bahwa ketidakpastian kebijakan ekonomi Amerika Serikat tidak berpengaruh signifikan terhadap pertumbuhan ekonomi China, dan Hong Kong. Bhagat et al., (2013) melakukan penelitian ketidakpastian kebijakan ekonomi terhadap pertumbuhan ekonomi di India. Hasil penelitian menunjukkan bahwa ketidakpastian kebijakan ekonomi berdampak negatif terhadap pertumbuhan ekonomi India. Sahinoz \& Cosar, (2018) menunjukkan bahwa ketidakpastian kebijakan ekonomi berdampak negatif terhadap pertumbuhan ekonomi Turki. Istiak \& Serletis, (2018) menujukkan bahwa ketidakpastian kebijakan ekonomi bersifat countercyclical di G7, yang pengaruhnya terhadap pertumbuhan ekonomi (Dutu, 2016) negara G7 adalah positif, tetapi pengaruhnya ketidakpastian kebijakan ekonomi terhadap pertumbuhan ekonomi per negara adalan negatif.

Allegret \& Benkhodja, (2015) melakukan penelitian tentang dampak harga minyak dunia terhadap pertumbuhan ekonomi di Algeria. Pengaruh harga minyak dunia terhadap pertumbuhan ekonomi di Algeria symmetric dan very weak. (Majidli \& Guliyev, 2020) menemukan bahwa kenaikan harga minyak meningkatkan pertumbuhan PDB non-minyak riil di negara Azerbaijan. Gylych et al., (2020) menunjukkan hasil bahwa harga minyak dunia berkontribusi besar terhadap kinerja pertumbuhan ekonomi negara Nigeria. Akinsola \& Odhiambo, (2020) menemukan bahwa kenaikan harga minyak memiliki dampak signifikan positif terhadap pertumbuhan ekonomi negara sub-Saharan African (SSA), sedangkan kenaikan harga minyak berpengaruh negatif signifikan terhadap pertumbuhan ekonomi negara subSaharan African (SSA).

Hasil penelitian Irsania \& Noveria, (2014) selama periode 1983-2012 menunjukkan variabel kurs rupiah/USD berpengaruh signifikan negatif terhadap pertumbuhan ekonomi Indonesia. Purba \& Magdalena, (2017) menunjukkan hasil penelitian perubahan nilai tukar memiliki pengaruh positif terhadap pertumbuhan ekonomi Indonesia. Anggraini \& Permatasari, (2020) melakukan penelitian dengan simpulan nilai tukar dolar berpengaruh 
positif dan signifikan terhadap perekonomian Indonesia. Penelitian Ramana \& Nasrudin, (2018) menunjukkan bahwa devaluasi yuan berdampak signifikan terhadap perekonomian Indonesia melalui jalur perdagangan dan investasi.

Studi ini menggunakan negara Indonesia untuk menguji dan menganalisis respon pertumbuhan ekonomi akibat shock eksternal dengan menggunakan periode 2004:I2020:I. Sepanjang periode tersebut terdapat banyak shock seperti ketidakpastian kebijakan ekonomi Amerika Serikat dan China, serta peningkatan atau penurunan harga minyak dunia. Studi tentang dampak shock kebijakan Amerika Serikat dan China terhadap pertumbuhan ekonomi Indonesia masih jarang ditemukan, sehingga diharapkan penelitrian ini memberikan kontribusi bagi kebijakan yang akan diambil. Tujuan penelitian, yaitu menguji dan menganalisis respon pertumbuhan ekonomi Indonesia akibat shock eksternal dari Amerika Serikat dan China.

\section{Kajian Teori}

Ketidakpastian kebijakan ekonomi mulai meningkat setelah terjadi krisis keuangan global, kemudian krisis berantai di Zona Euro, dan selanjutnya sengketa kebijakan partisan di Amerika Serikat. Ketidakpastian ekonomi dari Amerika Serikat dan Eropa berkontribusi pada penurunan ekonomi yang tajam pada tahun 2008-2009 dan pemulihan yang lambat setelah dampak tersebut (Alexopoulos \& Cohen, 2015). Ketidakpastian ekonomi tersebut dikembangkan dengan sebuah indeks. Pengembangan indeks tersebut dinamakan sebagai indeks ketidakpastian kebijakan ekonomi (EPU). Indeks tersebut mencerminkan frekuensi dari artikel berdasarkan 10 surat kabar terkemuka AS antara lain USA Today, Miami Herald, Chicago Tribune, Washington Post, Los Angeles Times, Boston Globe, San Francisco Chronicle, Dallas Morning News, New York Times, dan Wall Street Journal. Indeks tersebut juga menghitung ketidakpastian kebijakan ekonomi di 11 negara lainnya, termasuk negara G-10.

Teori selanjutnya yaitu tentang supply shock effect. Supply shock merupakan suatu keadaan secara tiba-tiba yang kemudian dapat merubah pasokan komoditas. Supply shock juga dapat dikatakan sebagai fenomena ekonomi yang datang secara tidak terduga. Fenomena supply shock dapat menyebabkan terjadinya kenaikan harga komoditas dan secara bersamaan akan menyebabkan penurunan produksi, sehingga perekonomian mengalami kontraksi. Supply shock secara ekonomi normatif dapat ditunjukkan dengan kurva permintaan agregat dan penawaran agregat, dimana kurva penawaran agregat bergeser ke kiri atas, dengan asumsi permintaan agregat dan kurva penawaran agregat jangka panjang tidak berubah.

Berdasarkan teori ekonomi, fakta bahwa nilai tukar sebagai variabel moneter dapat mempengaruhi pertumbuhan ekonomi melalui transmisi kebijakan moneter saluran nilai tukar. Pengaruh nilai tukar terhadap pertumbuhan ekonomi tergantung sistem nilai tukar yang diacu oleh suatu negara. Misalnya, dalam floating exchange rate system, kebijakan moneter yang longgar dapat mendorong depresiasi mata uang domestik dan meningkatkan harga barang impor. Hal ini akan mendorong kenaikan harga barang domestik. Kondisi ini akan menyebabkan penurunan pertumbuhan ekonomi, jika harga domestik tidak segera distabilkan.

\section{Metode}

\section{Rancangan Penelitian}

Penelitian ini menggunakan pendekatan kuantitatif, sehingga analisis studi ini lebih banyak menyajikan hasil pengolahan data ekonometrika. Metode kuantitatif dipilih karena dapat mengestimasi hubungan variabel ekonomi yang digunakan dalam penelitian. Selain itu, metode kuantitatif dapat menyederhanakan teori ekonomi kedalam model untuk diestimasi. Pengolahan ekonometrika menggunakan software STATA 14 dengan metode VECM. Data yang digunakan dalam studi ini dari tahun. Periode penelitian dalam studi ini 2004:I-2020:I. Periode ini dipilih karena masa recovery setelah krisis moneter dan sebelum pandemi covid 19 meluas di Indonesia. Periode tersebut digunakan karena banyak shock seperti ketidakpastian kebijakan ekonomi Amerika Serikat akibat krisis keuangan global dan ketidakpastian kebijakan ekonomi China akibat perang dagang, serta peningkatan atau penurunan harga minyak dunia.

\section{Jenis dan Sumber Data}

Studi ini menggunakan data sekunder. Data yang digunakan dalam studi ini antara lain pertumbuhan ekonomi Indonesia (\%), shock external seperti level kurs rupiah/usd, level kurs rupiah/rmb, ketidakpastian kebijakan ekonomi Amerika Serikat (indeks), ketidakpastian kebijakan ekonomi China (indeks), pertumbuhan ekonomi Amerika Serikat (\%), pertumbuhan ekonomi China (\%), dan harga minyak dunia (US\$). Sumber data diperoleh dari OECD, policy uncertainty, Bank Indonesia, dan Bloomberg (Tabel 1).

\section{Metode Analisis Data}

Metode yang digunakan dalam studi ini yaitu VECM. Ada beberapa langkah yang perlu dilakukan sebelum menguji dengan VECM. Langkah pertama yaitu melakukan uji stasioneritas pada variabel, langkah kedua yaitu pemilihan optimal lag, langkah ketiga yaitu uji kointegrasi dengan pendekatan Johansen, langkah keempat yaitu melakukan estimasi VECM, dan langkah kelima yaitu menguji stabilitas VECM, serta langkah keenam menganalisis impluse response dan variance decomposition. Software yang digunakan dalam penelitian ini STATA 14.

Langkah pertama uji stasioner data. Hal ini karena data ekonometrika yang digunakan dalam studi ini berjenis time series. Data time series jika tidak ada unit root, maka dikatakan stasioner. Metode yang dipakai untuk mendeteksi unit root yaitu ADF. Berikut ini persamaan ADF:

$$
\begin{array}{r}
\Delta y_{t}=\gamma+\delta \text { Trend }+\alpha y_{t-1}+\sum_{i=1}^{m} \beta_{i} \Delta y_{t-i} \\
+e_{t} \ldots \ldots \ldots \ldots \ldots \ldots \ldots \ldots
\end{array}
$$

Dimana $\Delta y_{t}$ adalah bentuk $\mathrm{y}_{\mathrm{t}}-\mathrm{y}_{\mathrm{t}-1}$ atau bentuk turunan pertama, $\gamma$ adalah konstanta ADF, y adalah variabel yang dicek stasioner, $\beta$ adalah parameter lag $\mathrm{y}, \mathrm{m}$ adalah panjang lag yang digunakan dalam model, Trend adalah trend waktu, $\delta$ adalah parameter dari trend, $e_{t}$ adalah gangguang dengan white noise. Uji stasioner dan non stasioner menggunakan uji ADF dengan cara melihat $p$-value ADF. 
Tabel 1. Jenis dan Sumber Data

\begin{tabular}{|c|c|c|c|c|c|}
\hline No & Variabel & Perhitungan & Satuan & $\begin{array}{l}\text { Sumber } \\
\text { Data }\end{array}$ & $\begin{array}{l}\text { Jenis } \\
\text { Data }\end{array}$ \\
\hline 1 & $\begin{array}{l}\text { Pertumbuhan } \\
\text { Ekonomi } \\
\text { Indonesia }\end{array}$ & $e g=\left(\frac{G D P R_{t}-G D P R_{t-1}}{G D P R_{t-1}}\right) \times 100 \%$ & persen & $\begin{array}{l}\text { Bank } \\
\text { Indonesia }\end{array}$ & Sekunde \\
\hline 2 & $\begin{array}{l}\text { Ketidakpastian } \\
\text { Kebijakan } \\
\text { Ekonomi US }\end{array}$ & gepuus $=\left(\frac{\text { epuus }_{t}-e^{e p u u s_{t-1}}}{\text { epuus }_{t-1}}\right) \times 100 \%$ & persen & $\begin{array}{l}\text { Policy } \\
\text { uncertainty }\end{array}$ & Sekunde \\
\hline 3 & $\begin{array}{l}\text { Ketidakpastian } \\
\text { Kebijakan } \\
\text { Ekonomi } \\
\text { China }\end{array}$ & gepuchina $=\left(\frac{\text { epuchina }_{t}-\text { epuchina }_{t-1}}{\text { epuchina }_{t-1}}\right) \times 100 \%$ & persen & $\begin{array}{l}\text { Policy } \\
\text { uncertainty }\end{array}$ & Sekunde \\
\hline 4 & $\begin{array}{l}\text { Pertumbuhan } \\
\text { Ekonomi US }\end{array}$ & $e g u s=\left(\frac{G D P R U S_{t}-G D P R U S_{t-1}}{G D P R U S_{t-1}}\right) \times 100 \%$ & persen & OECD & Sekunde \\
\hline 5 & $\begin{array}{l}\text { Pertumbuhan } \\
\text { Ekonomi } \\
\text { China }\end{array}$ & egchina $=\left(\frac{G D P R C h \text { hina }_{t}-G D P R C h i n a_{t-1}}{G D P R C h i n a_{t-1}}\right) \times 100 \%$ & persen & OECD & Sekunde \\
\hline 6 & $\begin{array}{l}\text { Harga Minyak } \\
\text { Dunia }\end{array}$ & Oil $=\left(\frac{\text { Oil Price }_{t}-\text { Oil Price }_{t-1}}{\text { Oil Price }_{t-1}}\right) \times 100 \%$ & persen & Bloomberg & Sekunde \\
\hline 7 & Kurs Rp/USD & $I D R / U S D=\left(\frac{R p / U S D_{t}-R p / U S D_{t-1}}{R p / U S D_{t-1}}\right) \times 100 \%$ & persen & $\begin{array}{l}\text { Bank } \\
\text { Indonesia }\end{array}$ & Sekunde \\
\hline 8 & Kurs Rp/RMB & $I D R / R M B=\left(\frac{R p / R M B_{t}-R p / R M B_{t-1}}{R p / R M B_{t-1}}\right) \times 100 \%$ & persen & $\begin{array}{c}\text { Bank } \\
\text { Indonesia }\end{array}$ & Sekunde \\
\hline
\end{tabular}

Jika probabilitas uji ADF kurang dari level of significance $1 \%, 5 \%$, atau $10 \%$, maka hipotesis nol diterima, sehingga dapat dikatakan bahwa tidak terdapat unit root atau stasioner. Jika probabilitas uji ADF melebihi level of significance $1 \%, 5 \%$, atau $10 \%$, maka hipotesis nol tidak diterima, sedangkan hipotesis alternatif diterima, artinya terdapat unit root atau stasioner.

Langkah kedua yaitu menentukan optimal lag untuk menganalisis VECM. Jika lag terlalu sedikit, maka residual dari regresi tidak akan menampilkan proses white noise, sehingga model tidak dapat mengestimasi actual error secara tepat, namun, jika lag terlalu panjang akan mengakibatkan banyak derajat kebebasan terbuang. Informasi yang direkomendasikan oleh Final Prediction Error (FPE), Akaike Information Criterion (AIC), Schwarz Bayesian Information Criterion (SBIC), dan HannanQuinn Information Criterion (HQIC). Berikut ini persamaan Final Prediction Error (FPE), Akaike Information Criterion (AIC), Schwarz Bayesian Information Criterion (SBIC), dan Hannan-Quinn Information Criterion (HQIC) dengan pendekatan (Lütkepohl, 2005):

$A I C=\ln \left(\left|\sum_{u}\right|\right)+\frac{2 p K^{2}}{T}$.

$S B I C=\ln \left(\left|\sum_{u}\right|\right)+$

$\frac{\ln (T)}{T} p K^{2}$

$H Q I C=\ln \left(\left|\sum_{u}\right|\right)+$

$\frac{2 \ln \{\ln (T)\}}{T} p K^{2}$

$F P E=$

$\left|\sum_{u}\right|\left(\frac{T+K p+1}{T-K p-1}\right)^{K}$

Langkah ketiga yaitu menguji kointegrasi dengan pendekatan Johansen. Data terkointegrasi atau tidak dapat diketahui menggunakan uji yang dikembangkan oleh Johansen. Uji kointegrasi Johansen tersebut dilakukan dengan cara membandingkan nilai Max-Eigen dan nilai trace-nya. Hipotesis nol menunjukkan tidak ada kointegrasi. Kriterianya yaitu jika nilai Max-Eigen dan nilai trace-nya lebih rendah dari $1 \%, 5 \%$, atau $10 \%$, maka hipotesis nol ditolak, sehingga hipotesis alternatif diterima, artinya data terkointegrasi dan mempunyai hubungan jangka panjang.

Pasca melakukan uji kointegrasi maka melakukan estimasi VECM. Eangle dan Granger (1987) merupakan orang yang pertama kali mempopulerkan metode VECM (Vector Error Correction Model). Eangle dan Granger (1987) melakukan koreksi ketidakseimbangan jangka pendek terhadap jangka panjang menggunakan VECM. VECM sebenarnya bagian dari VAR yang terestriksi. Adanya restriksi tersebut diberikan sebab data VECM data yang tidak stasioner tetapi ada kointegrasi.

Keuntungan dari VECM misalnya mampu menjelaskan fenomena ekonomi dalam jangka pendek dan jangka panjang, serta dapat menjadi solusi dalam persoalan variabel time series yang tidak stasioner pada tingkat level, sehingga masalah regresi lancung atau korelasi lancung (spurious regression) dalam analisis ekonometrika dapat diatasi. Asumsi yang harus dipenuhi dalam analisis VECM adalah semua variabel independen harus bersifat stasioner pada tingkat $\mathrm{I}(0)$ dan terkointegrasi. Hal ini ditandai dengan nilai rata-rata nol, ragam konstan dan diantara variabel tak bebas tidak ada korelasi. Berikut model estimasi VECM dalam studi ini:

$$
\begin{aligned}
& \Delta e g_{t}=\alpha+\sum_{i=1}^{k-1} \beta_{1} \Delta e g_{t-i}+\sum_{j=1}^{k-1} \beta_{2} \Delta g e p u U S_{t-j}+ \\
& \sum_{m=1}^{k-1} \beta_{3} \Delta \text { gepuChina }_{t-m}+\sum_{n=1}^{k-1} \beta_{4} \Delta \text { oil }_{t-n}+ \\
& \sum_{p=1}^{k-1} \beta_{5} \Delta \text { egUS } S_{t-p}+\sum_{q=1}^{k-1} \beta_{6} \Delta \text { egChina } \text { h }_{t-q}+ \\
& \sum_{r=1}^{k-1} \beta_{7} \Delta R p / U S D_{t-r}+\sum_{s=1}^{k-1} \beta_{8} \Delta R p / R M B_{t-s}+ \\
& \gamma E C T_{t-1}+u_{t} \ldots \ldots \ldots \ldots \ldots \ldots \ldots \ldots \ldots \ldots \ldots .(6)
\end{aligned}
$$

dimana eg, epuUS, epuChina, oil, egUS, egChina, $\mathrm{Rp} / \mathrm{USD}$, dan $\mathrm{Rp} / \mathrm{RMB}$ adalah pertumbuhan ekonomi 
Indonesia, ketidakpastian kebijakan ekonomi Amerika Serikat, ketidakpastian kebijakan ekonomi China, harga minyak dunia, pertumbuhan ekonomi Amerika Serikat, pertumbuhan ekonomi China, kurs rupiah/US dolar, dan kurs rupiah/RMB. Variabel-variabel tersebut sebagai variabel endogen. $\alpha$ menunjukkan konstanta, $\beta_{1} \ldots \beta_{8}$ menunjukkan koefisien jangka pendek, $\gamma$ menunjukkan speed of adjustment parameter dengan tanda negatif, dan $\mathrm{ECT}_{\mathrm{t}-1}$ menunjukkan error correction term, serta $u_{t}$ menunjukkan error term.

Langkah setelah melakukan estimasi VECM untuk jangka panjang dan jangka pendek yaitu menguji stabilitas VECM. Hal ini bertujuan untuk memeriksa kondisi stabilitas eigen value setelah memperkirakan parameter VECM. Jika stabil, maka infinite order vector movingaverage representation. Selain itu, jika stabil, maka fungsi impluse response dan Forecast Error Variance Decomposition (FEVD) memiliki interpretasi yang dapat dianalisis.

Impluse respon dalam metode VECM juga digunakan mengintrepretasikan persamaan model VECM. Salah satu fungsi dari impluse response yaitu pergerakan shock suatu variabel terhadap variabel lainnya dan dapat terlihat pengaruhnya dalam jangka panjang atau back to equilibrium point. Kontribusi dari masing-masing variabel terhadap variabel yang diamati dapat menggunakan Forecast Error Variance Decomposition (FEVD).

\section{Hasil Analisis dan Pembahasan}

Hasil analisis dan pembahasan dilakukan dengan pendekatan kuantitatif yang didasarkan pada statistik dan ekonometrika. Hasil penelitian tersebut diperoleh dengan mengambil sebagian sampel secara random dari jumlah populasi.

Tabel 2 menunjukkan rata-rata pertumbuhan ekonomi Indonesia sebelum periode krisis keuangan global sebesar 5,6 persen dengan minimal 4,1 persen dan maksimal 7,16 persen, serta standar deviasi sebesar 0,0088. Rata-rata pertumbuhan ekonomi Indonesia periode krisis keuangan global sebesar 5,39 persen dengan minimal 2,97 persen dan maksimal 6,89 persen, serta standar deviasi sebesar 0,0075. Hal ini menandakan bahwa krisis keuangan global berdampak pada penurunan pertumbuhan ekonomi, tetapi penurunan tersebut masih positif, sehingga kekuatan domestik Indonesia dapat dikatakan cukup kuat dan kontraksi pertumbuhan ekonomi Indonesia tidak terlalu dalam. Pertumbuhan ekonomi Amerika Serikat dan China sebelum krisis keuangan global masih positif. Pertumbuhan ekonomi China tinggi sebesar 12,13 persen sedangkan Amerika Serikat sebesar 3,01 persen. Periode krisis keuangan global pertumbuhan ekonomi kedua negara tersebut turun menjadi 1,7 persen dan 7,66 persen. Kedua negara tersebut secara rata-rata mengalami kontraksi 1,3 persen untuk Amerika Serikat, sedangkan China terkontraksi hampir sebesar 4,5 persen. Hasil

Tabel 2. Statistik Deskriptif

\begin{tabular}{lcccc}
\hline Periode 2004:I-2020:I (Periode Total) & \multicolumn{5}{l}{ Mean } & Min & Max & Std. Deviasi \\
\hline Variabel & Mean & $2,97 \%$ & $7,16 \%$ & 0,0078 \\
Pertumbuhan Ekonomi Indonesia & $7,40 \%$ & $-45,75 \%$ & $101.89 \%$ & 0,3256 \\
Ketidakpastian Kebijakan Ekonomi US & $26,11 \%$ & $-61,89 \%$ & $186,21 \%$ & 0,6091 \\
Ketidakpastian Kebijakan Ekonomi China & $2,02 \%$ & $-3,92 \%$ & $4,30 \%$ & 0,0164 \\
Pertumbuhan Ekonomi US & $8,76 \%$ & $-6,80 \%$ & $15,0 \%$ & 0,0312 \\
Pertumbuhan Ekonomi China & $8,66 \%$ & $-55 \%$ & $98 \%$ & 0,3438 \\
Harga Minyak Dunia & $3,52 \%$ & $-20,29 \%$ & $25,76 \%$ & 0.0893 \\
Kurs Rp/USD & $4,94 \%$ & $-21,25 \%$ & $29,95 \%$ & 0,1024 \\
Kurs Rp/RMB & $5,6 \%$ & $4,10 \%$ & $7,16 \%$ & 0,0088 \\
Periode 2004:I-2007:IV (Periode Sebelum Krisis Keuangan Global) & & 0,2923 \\
Pertumbuhan Ekonomi Indonesia & $-2,42 \%$ & $-40,81 \%$ & $71,28 \%$ & 0,3251 \\
Ketidakpastian Kebijakan Ekonomi US & $0,66 \%$ & $-46,01 \%$ & $64,93 \%$ & 0,0085 \\
Ketidakpastian Kebijakan Ekonomi China & $3,01 \%$ & $1,48 \%$ & $4,30 \%$ & 0,0173 \\
Pertumbuhan Ekonomi US & $12,13 \%$ & $8,80 \%$ & $15,0 \%$ & 0,2121 \\
Pertumbuhan Ekonomi China & $25,81 \%$ & $-5,00 \%$ & $62,00 \%$ & 0,0645 \\
Harga Minyak Dunia & $18,03 \%$ & $-8,75 \%$ & $9,55 \%$ & 0,0716 \\
Kurs Rp/USD & $4,61 \%$ & $-8,54 \%$ & $15,14 \%$ & \\
Kurs Rp/RMB & & & 0,0075 \\
Periode 2008:I-2020:I (Periode Krisis Keuangan Global) & $5,39 \%$ & $2,97 \%$ & $6,89 \%$ & 0,3323 \\
Pertumbuhan Ekonomi Indonesia & $10,60 \%$ & $-45,75 \%$ & $101,89 \%$ & 0,6580 \\
Ketidakpastian Kebijakan Ekonomi US & $34,41 \%$ & $-61,89 \%$ & $186,21 \%$ & 0,0171 \\
Ketidakpastian Kebijakan Ekonomi China & $1,70 \%$ & $-3,92 \%$ & $4,00 \%$ & 0,0265 \\
Pertumbuhan Ekonomi US & $7,66 \%$ & $-6,80 \%$ & $12,2 \%$ & 0,3613 \\
Pertumbuhan Ekonomi China & $3,06 \%$ & $-55 \%$ & $98 \%$ & 0,0959 \\
Harga Minyak Dunia & $4,08 \%$ & $2,97 \%$ & $6,89 \%$ & 0,1112 \\
Kurs Rp/USD & $5,05 \%$ & $-21,25 \%$ & $29,95 \%$ & \\
Kurs Rp/RMB & & & & \\
& & &
\end{tabular}


tersebut memberikan informasi bahwa China terkontraksi cukup dalam.

Rata-rata pertumbuhan indeks ketidakpastian kebijakan ekonomi Amerika Serikat dan China cukup berbeda signifikan antara periode sebelum krisis keuangan global dengan periode krisis keuangan global. Periode sebelum krisis keuangan global rata-rata pertumbuhan indeks ketidakpastian kebijakan ekonomi Amerika Serikat -2,42 persen dan China 0,66 persen, sedangkan periode krisis keuangan global rata-rata pertumbuhan indeks ketidakpastian kebijakan ekonomi Amerika Serikat 10,60 persen dan China 34,41 persen. Perubahan tersebut memberikan arti bahwa masa periode krisis keuangan global ketidakpastian kebijakan ekonomi kedua negara cukup tinggi. Lembaga moneter dan fiskal di kedua negara tersebut terdampak krisis keuangan global sehingga sering menghadapi ketidakpastian efek dari keputusan kebijakan dalam negeri maupun luar negeri.

Rata-rata tingkat tekanan rupiah terhadap dolar sebelum krisis keuangan global cukup tinggi yaitu sebesar 18,03 persen dan tekanan rupiah terhadap RMB sebesar 4,61 persen, lebih rendah dari dolar. Sepanjang periode 2004:I2007:IV rupiah sering mengalami depresiasi terhadap dolar, dan apresiasi terhadap RMB. Tekanan rupiah akibat dolar menguat tersebut membuat kondisi pasar valuta asing cukup mengkhawatirkan. Kondisi berbeda periode 2008:I2020:I, karena rata-rata tekanan rupiah terhadap dolar periode krisis keuangan sangat berkurang, yaitu sebesar 4,08 persen, tetapi tekanan rupiah terhadap RMB meningkat menjadi 5,05 persen. Hal ini mengindikasikan bahwa rupiah lebih banyak apresiasi terhadap dolar, sedangkan depresiasi terhadap RMB. Kondisi tersebut didorong kebijakan China melemahkan mata uangnya. Kebijakan tersebut membuat sebagian besar nilai tukar mata uang global langsung melemah. Rata-rata harga minyak dunia mengalami penurunan yang cukup signifikan selama periode krisis keuangan dari 25,81 persen menjadi 3,06 persen. Hal ini diakibatkan cadangan minyak tinggi akibat krisis keuangan global, dan ditambah dengan ketegangan antara Amerika Serikat dan China.

Tabel 3 menunjukkan bahwa pada $\mathrm{I}(0)$ pertumbuhan ekonomi Amerika Serikat, pertumbuhan ekonomi China, dan kurs rupiah/dolar tidak stasioner. Hal ini ditunjukkan dengan probabilitas ADF lebih dari 1\%, 5\%, dan 10\%, sehingga $\mathrm{H} 0$ menunjukkan tidak terdapat unit root ditolak, sedangkan pertumbuhan ekonomi dan kurs rupiah/RMB stasioner pada tingkat $10 \%$, ketidakpastian kebijakan ekonomi Amerika Serikat dan China stasioner pada tingkat $1 \%$, dan harga minyak dunia stasioner pada tingkat $5 \%$. Selanjutnya dilakukan proses first difference I(1) untuk semua variabel. Hasil I(1) menunjukkan bahwa semua variabel stasioner pada tingkat $1 \%$, sehingga hipotesia nol yang menunjukkan tidak ada unit root tidak ditolak dan terbebas dari masalah sporious regression.

Langkah berikutnya yaitu melakukan uji lag optimal. Uji ini penting dilakukan dalam analisis data time series karena kointegrasi dan uji VECM sangat sensitif terhadap panjang lag. Lag yang terlalu pendek akan menghasilkan korelasi serial sedangkan lag yang terlalu panjang, maka mengakibatkan penurunan df, sehingga banyak parameter yang diestimasi menjadi tidak efisien.

Tabel 4 menunjukkan bahwa HQIC dan SBIC merekomendasikan lag 0 sedangkan FPE dan AIC merekomendasikan lag 4. Berdasarkan pada rasionalitas metode dinamis maka lag optimal yang disarankan pada HQIC dan SBIC ditolak. Hal ini karena lag 0 nantinya model tidak bersifat dinamis, sehingga model tidak dapat digunakan. Studi ini memilih pendekatan AIC dengan lag optimal 4.

Tabel 5 menunjukkan uji Kointegrasi dengan pendekatan Johansen. Hasil estimasi kointegrasi Johansen menunjukkan bahwa terdapat kointegrasi dengan rank

Tabel 3. Uji Stasioner ADF

\begin{tabular}{llc}
\hline Variabel & $\mathrm{I}(0)$ & $\mathrm{I}(1)$ \\
\hline Pertumbuhan Ekonomi Indonesia & $0,0599 *$ & $0,0000^{* * *}$ \\
Ketidakpastian Kebijakan Ekonomi US & $0,0004^{* * *}$ & $0,0000^{* * *}$ \\
Ketidakpastian Kebijakan Ekonomi China & $0,0005 * * *$ & $0,0000^{* * *}$ \\
Pertumbuhan Ekonomi US & 0,4765 & $0,0000^{* * *}$ \\
Pertumbuhan Ekonomi China & 0,8096 & $0,0000^{* * *}$ \\
Harga Minyak Dunia & $0,0106^{* *}$ & $0,0000^{* * *}$ \\
Kurs Rp/USD & 0,1878 & $0,0000^{* * *}$ \\
Kurs Rp/RMB & $0,0935^{*}$ & $0,0000^{* * *}$
\end{tabular}

Keterangan: ***, **, * adalah stasioner pada $1 \%, 5 \%$, dan $10 \%$

Tabel 4. Uji Lag Optimal

\begin{tabular}{ccccccccc}
\hline Lag & LL & LR & df & p & FPE & AIC & HQIC & SBIC \\
\hline 0 & 745,858 & & & & $2,90 \mathrm{E}-21$ & $-47,5649$ & $-47,5649 *$ & $-47,5649 *$ \\
1 & 813,547 & 135,38 & 64 & 0 & $2,60 \mathrm{E}-21$ & $-47,6879$ & $-46,8141$ & $-45,4539$ \\
2 & 890,349 & 153,6 & 64 & 0 & $1,90 \mathrm{E}-21$ & $-48,1146$ & $-46,367$ & $-43,6467$ \\
3 & 956,071 & 131,45 & 64 & 0 & $2,40 \mathrm{E}-21$ & $-48,1721$ & $-45,5506$ & $-41,4702$ \\
4 & 1049,02 & $185,89 *$ & 64 & 0 & $1,8 \mathrm{e}-21 *$ & $-49,1369 *$ & $-45,6416$ & $-40,201$ \\
\hline
\end{tabular}


sebanyak 6, sehingga hipotesis nol yang menyatakan tidak ada kointegrasi dapat ditolak, dan hipotesis alternatif yang menyatakan ada kointegrasi tidak dapat ditolak.

Tabel 5. Uji Kointegrasi Johansen

\begin{tabular}{ccc}
\hline $\begin{array}{c}\text { Maksimal } \\
\text { Rank }\end{array}$ & $\begin{array}{c}\text { Trace } \\
\text { Statistik }\end{array}$ & $\begin{array}{c}5 \% \\
\text { Critical Value }\end{array}$ \\
\hline 0 & 284,3342 & 156 \\
1 & 203,3684 & 124,24 \\
2 & 141,6539 & 94,15 \\
3 & 92,1517 & 68,52 \\
4 & 57,5507 & 47,21 \\
5 & 30,0555 & 29,68 \\
6 & $9,4571^{*}$ & 15,41 \\
7 & 0,1331 & 3,76 \\
\hline
\end{tabular}

\section{Hasil estimasi Jangka Panjang}

Hasil estimasi VECM dalam jangka panjang menunjukkan bahwa semua variabel berpengaruh signifikan terhadap pertumbuhan ekonomi Indonesia. Hal ini memberikan arti bahwa shock external tersebut dapat mempengaruhi kinerja pertumbuhan ekonomi Indonesia, sehingga perubahan dalam variabel-variabel tersebut menjadi sinyal yang harus diantisipasi oleh lembaga moneter dan fiskal, supaya tidak berisiko besar bagi perekonomian Indonesia. Perlu dipahami bahwa koefisien VECM di intrepretasi berkebalikan, artinya hasil estimasi positif, maka intrepretasinya negatif, begitu juga sebaliknya. Ketidakpastian kebijakan ekonomi Amerika Serikat berdampak positif terhadap pertumbuhan ekonomi Indonesia, sedangkan China sebaliknya. Pertumbuhan ekonomi Amerika Serikat dan China berdampak positif terhadap pertumbuhan ekonomi Indonesia. Harga minyak dunia juga berdampak positif terhadap pertumbuhan ekonomi Indonesia. Kurs rupiah/dolar berdampak positif terhadap pertumbuhan ekonomi Indonesia, sedangkan kurs rupiah/RMB berdampak negatif terhadap pertumbuhan ekonomi Indonesia.

Ketidakpastian kebijakan ekonomi Amerika Serikat dan China berpengaruh positif dan signifikan terhadap pertumbuhan ekonomi Indonesia. Hasil estimasi ini didukung penelitian Bhagat et al., (2013) yang menunjukkan bahwa ketidakpastian kebijakan ekonomi berdampak signifikan terhadap pertumbuhan ekonomi India. Sahinoz \& Cosar, (2018) juga menunjukkan bahwa ketidakpastian kebijakan ekonomi berdampak signifikan terhadap pertumbuhan ekonomi Turki. Hasil estimasi tersebut menunjukkan bahwa pengaruh ketidakpastian kebijakan ekonomi Amerika Serikat lebih besar dibandingkan dengan China. Hal ini karena ekonomi Amerika Serikat merupakan yang terbesar dan paling produktif serta paling kompetitif di dunia sehingga berdampak pada ekonomi Indonesia. Hasil tersebut menunjukkan bahwa pertumbuhan ekonomi Indonesia masih kuat ditengah ketidakpastian ini juga didorong oleh kekuatan fundamental makroekonomi Indonesia, sebab sektor konsumsi dinilai masih kuat, sehingga sektor konsumsi masih bisa diandalkan untuk mendorong pertumbuhan ekonomi Indonesia. Pemerintah Indonesia juga masih mengandalkan kebijakan fiskal untuk menjaga kondisi ekonomi yang penuh dengan ketidakpastian. Hal ini dengan memberikan insentif-insentif yang dirasa memang diperlukan. Intermediasi sektor jasa keuangan juga tercatat membukukan perkembangan yang stabil dengan profil risiko yang terkendali.

Pengaruh pertumbuhan ekonomi Amerika Serikat dan China berdampak searah pada pertumbuhan ekonomi Indonesia. Jika pertumbuhan ekonomi kedua negara tersebut melambat, maka berpotensi menghambat pertumbuhan ekonomi Indonesia. Hal ini karena kedua negara tersebut adalah dua mitra dagang utama Indonesia, sehingga memiliki relasi yang cukup kuat dengan pertumbuhan ekonomi Indonesia. Pelemahan ekonomi keduanya bisa membuat permintaan barang dari Indonesia (ekspor) ikut turun. Padahal ekspor merupakan salah satu pendorong pertumbuhan ekonomi Indonesia. Kondisi tersebut Pemerintah Indonesia dapat mengantisipasi perlambatan ekspor dengan mendorong investasi. Selain investasi, konsumsi rumah tangga juga terus ditingkatkan. Harga minyak dunia mengalami peningkatan atau penurunan mendapat perhatian dari negara produsen minyak mentah maupun negara konsumen. Hal ini karena komoditas tersebut sangat penting sebagai bahan bakar transportasi dan input melakukan produksi. Minyak sebagai bahan bakar transportasi bermanfaat untuk distribusi, sedangkan sebagai input produksi bermanfaat untuk menghasilkan listrik, dan menjalankan mesin produksi.

Tabel 6. Hasil Estimasi Jangka Panjang

\begin{tabular}{lc}
\hline Variabel & Estimasi \\
\hline Ketidakpastian Kebijakan Ekonomi & $-0,0465^{* * *}$ \\
US & $(0,0150)$ \\
Ketidakpastian Kebijakan Ekonomi & $-0,0889^{* * *}$ \\
China & $(0,0060)$ \\
Pertumbuhan Ekonomi US & $-0,5065^{* *}$ \\
& $(0,2294)$ \\
Pertumbuhan Ekonomi China & $-0,8560 * * *$ \\
Harga Minyak Dunia & $(0,2706)$ \\
& $0,0594 * * *$ \\
Kurs Rp/USD & $(0,0102)$ \\
& $-0,3675^{* * *}$ \\
Kurs Rp/RMB & $(0,0087)$ \\
\end{tabular}

Keterangan: ***,**, * adalah signifikan pada $1 \%, 5 \%$, dan $10 \%$

Hasil estimasi pada Tabel 6 memberikan informasi bahwa world oil price atau harga minyak dunia berpengaruh negatif terhadap pertumbuhan ekonomi Indonesia. Hal ini sejalan dengan penelitian Allegret \& Benkhodja, (2015) yaitu pengaruh world oil price terhadap pertumbuhan ekonomi di Algeria symmetric dan very weak. Penelitian lainnya yaitu Majidli \& Guliyev, (2020) menemukan bahwa kenaikan harga minyak meningkatkan pertumbuhan PDB non-minyak riil di negara Azerbaijan. Gylych et al., (2020) juga menunjukkan hasil bahwa harga minyak dunia berkontribusi besar terhadap kinerja pertumbuhan ekonomi negara Nigeria. Akinsola \& Odhiambo, (2020) menemukan bahwa kenaikan harga minyak memiliki pengaruh positif dan signifikan terhadap pertumbuhan ekonomi negara sub-Saharan African (SSA), sedangkan kenaikan harga minyak berpengaruh negatif signifikan 
terhadap pertumbuhan ekonomi negara sub-Saharan African (SSA).

Indonesia dahulu pernah menjadi salah satu negara pengekspor minyak bumi dan tergabung menjadi anggota OPEC, tetapi sejak tahun 2004 sampai saat ini berubah menjadi negara pengimpor minyak. Hal ini karena permintaan minyak lebih besar dibandingkan penawaran minyak, sehingga untuk menutupi kebutuhan minyak tersebut, maka Indonesia melakukan impor minyak. Shock harganya minyak dunia terhadap pertumbuhan ekonomi Indonesia dapat melalui supply side shock effect. Supply side shock effect, kenaikan harga minyak dunia menyebabkan penggunaan input produksi minyak menurun, sebab perusahaan memilih untuk melakukan penghematan. Hal ini dapat menghambat produktivitas perusahaan, sehingga output mengalami penurunan. Kenaikan harga minyak dunia merupakan shock yang dapat menimbulkan peningkatan marginal cost perusahaan, sehingga perusahaan mengurangi produksi. Kondisi tersebut memperlambat pertumbuhan ekonomi. Jika kenaikan harga minyak dunia berkelanjutan, maka dapat berakibat resesi ekonomi.

Kurs rupiah/dolar Amerika Serikat berpengaruh positif signifikan terhadap pertumbuhan ekonomi Indonesia. Hasil studi ini sejalan dengan Irsania \& Noveria, (2014) yaitu selama periode 1983-2012 menunjukkan variabel kurs rupiah/USD berpengaruh signifikan negatif terhadap pertumbuhan ekonomi Indonesia. Purba \& Magdalena, (2017) menunjukkan hasil penelitian perubahan nilai tukar memiliki pengaruh positif terhadap pertumbuhan ekonomi Indonesia. Anggraini \& Permatasari, (2020) melakukan penelitian dengan simpulan nilai tukar dolar berpengaruh positif dan signifikan terhadap perekonomian Indonesia. Hal ini memberikan arti bahwa depresiasi kurs rupiah/dolar Amerika Serikat dapat mendorong pertumbuhan ekonomi Indonesia. Kebijakan moneter transmisi kurs dapat menstabilkan kurs rupiah yang terdepresiasi. Transmisi kurs tersebut dijalankan oleh Bank Indonesia dengan meningkatkan suku bunga.

Kebijakan moneter kontraktif dengan meningkatkan suku bunga acuan. Kenaikan suku bunga acuan bertujuan untuk memperkecil gap dengan suku bunga dunia, sehingga dapat menarik capital inflow ke Indonesia dan pada akhirnya berdampak positif terhadap pertumbuhan ekonomi Indonesia. BI juga akan melakukan intervensi ganda di pasar valas dan pasar surat berharga negara. Strategi operasi moneter juga diarahkan untuk menjaga kecukupan likuiditas di pasar uang rupiah dan pasar swap antara bank. Dari sisi pemerintah, merespon kebijakan moneter kontraktif dengan merumuskan ulang insentif pajak, sehingga memperluas basis sektor penerima insentif perpajakan. Tujuan kebijakan fiskal tersebut untuk mendorong investasi.

Kurs rupiah/RMB berpengaruh signifikan negatif terhadap pertumbuhan ekonomi Indonesia. Penelitian Ramana \& Nasrudin, (2018) menunjukkan bahwa devaluasi yuan berdampak signifikan terhadap perekonomian Indonesia melalui jalur perdagangan dan investasi. Pelemahan kurs RMB terjadi karena Pemerintah China melakukan devaluasi mata uangnya. Secara teori, ketika kurs RMB melemah terhadap rupiah, maka harga produk China menjadi relatif lebih murah di pasar internasional. Kurs RMB melemah dapat berpotensi mendorong impor dari
China ke Indonesia lebih besar, sehingga defisit neraca perdagangan dengan China semakin melebar. Impor yang terlalu tinggi akan berpotensi mendorong inflasi. Hal ini mengindikasikan bahwa ketergantungan impor Indonesia dari China masih cukup tinggi.

\section{Hasil Estimasi Jangka Pendek}

Hasil jangka pendek lebih banyak yang tidak berpengaruh signifikan terhadap pertumbuhan ekonomi Indonesia. Hasil estimasi jangka pendek yang dimasukkan dalam Tabel 7 merupakan variabel yang berpengaruh signifikan terhadap pertumbuhan ekonomi. Persamaan VECM jangka pendek tidak perlu merubah tanda koefisien, sehingga lag 1 dan lag 2 pertumbuhan ekonomi Indonesia berpengaruh signifikan terhadap pertumbuhan ekonomi Indonesia, artinya pertumbuhan ekonomi masih dipengaruhi periode-periode sebelumnya, tetapi pengaruhnya semakin menurun.

Tabel 7. Hasil Estimasi Jangka Pendek

\begin{tabular}{|c|c|}
\hline Variabel & Estimasi \\
\hline L. $\Delta$ Pertumbuhan Ekonomi Indonesia & $\begin{array}{c}0,5582 * * * \\
(0,0949)\end{array}$ \\
\hline L2. $\Delta$ Pertumbuhan Ekonomi Indonesia & $\begin{array}{l}0.3555 * * * \\
(0,0207)\end{array}$ \\
\hline $\begin{array}{l}\text { L2. } \Delta \text { Ketidakpastian Kebijakan } \\
\text { Ekonomi China }\end{array}$ & $\begin{array}{l}0,0036^{*} \\
(0,0019)\end{array}$ \\
\hline ECT & $\begin{array}{c}-0,3035^{* * *} * \\
(0,0063)\end{array}$ \\
\hline
\end{tabular}

Ketidakpastian kebijakan ekonomi China ternyata masih berpengaruh terhadap pertumbuhan ekonomi meskipun dalam jangka pendek. Ketidakpastian kebijakan ekonomi China pada lag 2 berdampak positif terhadap pertumbuhan ekonomi Indonesia. Pengaruhnya terhadap pertumbuhan ekonomi Indonesia lebih kecil dibandingkan dalam jangka panjang. Koefisien ECT sebesar -0,3035 dan signifikan terhadap pertumbuhan ekonomi Indonesia, artinya valid digunakan dan dapat dianalisis kecepatan penyesuaian pertumbuhan ekonomi Indonesia. Nilai ECT sebesar 0,3035 berarti kecepatan penyesuaian pertumbuhan ekonomi Indonesia dari jangka panjang ke jangka pendek sebesar 30,35 persen. Penyimpangan tersebut akan kembali dalam waktu 3 kuartal lebih 2 bulan (1/0,3035). Langkah selanjutnya yaitu menguji stabil atau tidaknya estimasi VECM yang telah ditentukan atau istilahnnya

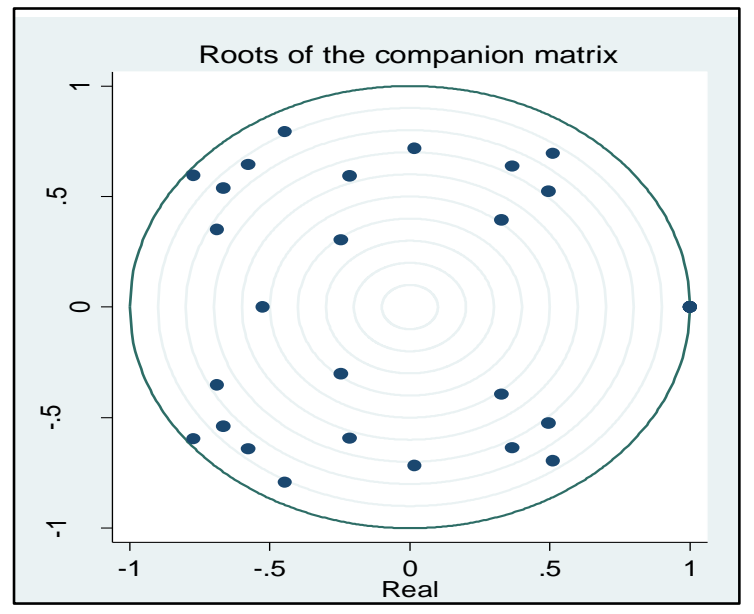

Gambar 1. Stabilitas Parameter VECM 
condition stability check. Uji tersebut yakni berupa roots of characteristic polynominal.

Suatu model VECM dikatakan stabil jika seluruh roots nya memiliki modulus lebih kecil dari 1 atau tidak berada diluar lingkaran. Hasil yang ditunjukkan Gambar 1 bahwa model VECM stabil karena tidak ada yang keluar dari lingkaran. Gambar 2 menunjukkan bahwa respon perubahan pertumbuhan ekonomi Indonesia lebih sensitif terhadap perubahan ketidakpastian kebijakan ekonomi Amerika Serikat dibandingkan dengan China. Penyebab ketidakpastian kebijakan Amerika Serikat dan China adalah krisis keuangan global, perang dagang China dan Amerika Serikat, reformasi struktural China yang tidak berjalan lancar, devaluasi RMB, serta krisis politik Hong Kong.
Amerika Serikat telah menjadi sumber ketidakpastian ekonomi global sehingga berdampak pada ekonomi Indonesia. Ketidakpastian kebijakan ekonomi Amerika Serikat menyebabkan tingginya persepsi risiko investor pada pasar keuangan Indonesia, sehingga berdampak pada kinerja pertumbuhan ekonomi Indonesia. Hal ini juga memberikan arti bahwa Pemerintah Indonesia lebih mampu memitigasi dampak ketidakpastian kebijakan ekonomi China dibandingkan Amerika Serikat. Makna lain yaitu kebijakan makroekonomi yang diterapkan oleh Indonesia ternyata belum optimal dalam mestabilkan dampak ketidakpastian kebijakan ekonomi Amerika Serikat.

Tahun pertama shock perubahan ketidakpastian kebijakan ekonomi Amerika Serikat dan China direspon negatif oleh

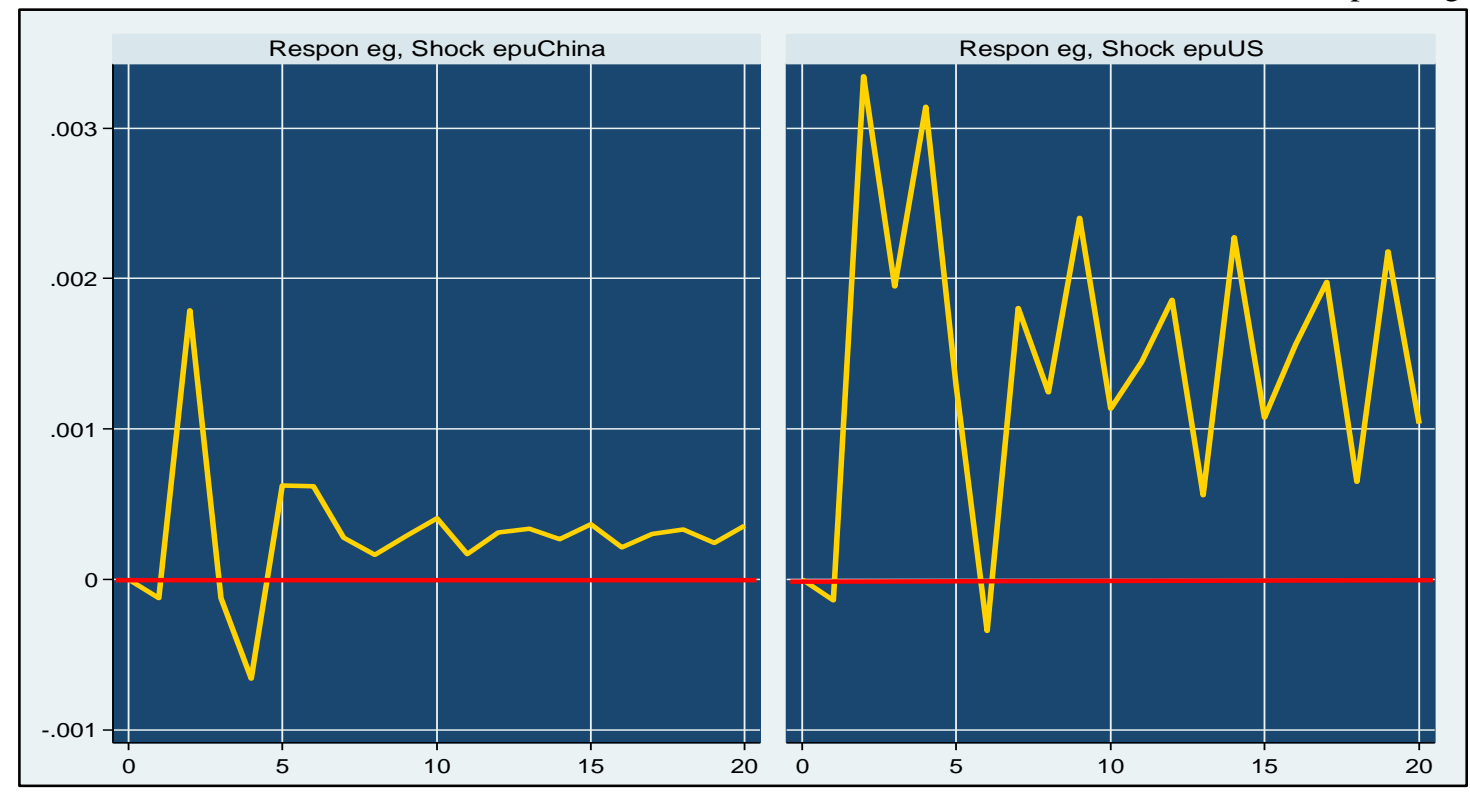

Gambar 2. Respon Pertumbuhan Ekonomi Indonesia Akibat Shock Ketidakpastian Kebijakan Ekonomi China dan Amerika Serikat

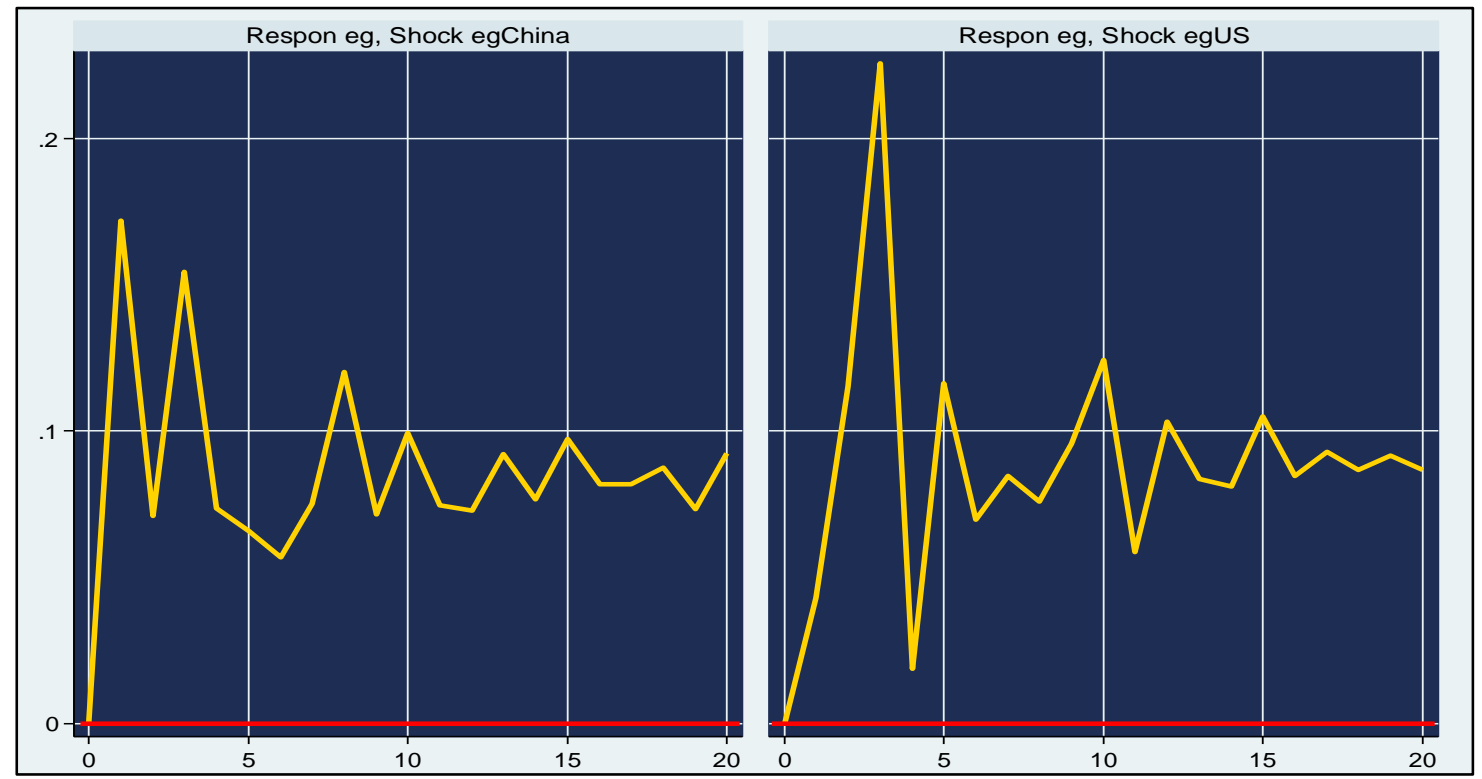

Gambar 3. Respon Pertumbuhan Ekonomi Indonesia Akibat Shock Pertumbuhan Ekonomi China dan Amerika Serikat 
perubahan pertumbuhan ekonomi Indonesia, namun selanjutnya direspon tinggi dan positif. Ternyata respon tersebut tidak berlangsung lama, ketidakpastian kebijakan ekonomi China tahun ke 3 dan 4 respon perubahan pertumbuhan ekonomi Indonesia menurun sampai negatif, sedangkan perubahan ketidakpastian kebijakan ekonomi Amerika Serikat tahun ke 4 sampai 6 direspon oleh perubahan pertumbuhan ekonomi Indonesia menurun sampai menyentuh angka negatif. Perubahan Ketidakpastian kebijakan ekonomi China direspon positif dan relatif stabil oleh perubahan pertumbuhan ekonomi Indonesia tahun ke 6 sampai 20. Perubahan ketidakpastian kebijakan ekonomi Amerika Serikat direspon positif dan fluktuatif oleh perubahan pertumbuhan ekonomi Indonesia tahun ke 6 sampai 20, sehingga belum ada tanda-tanda kembali ke titik keseimbangan.

Gambar 3 menunjukkan respon perubahan pertumbuhan ekonomi Indonesia akibat shock perubahan pertumbuhan ekonomi Amerika Serikat dan China. Perubahan pertumbuhan ekonomi Indonesia merespon positif shock perubahan pertumbuhan ekonomi Amerika Serikat dan China, artinya pergerakan siklus bisnis Amerika Serikat dan China adalah searah dengan Indonesia. Jika Amerika Serikat dan Cina mengalami ekspansi maka Indonesia juga mengalami ekspansi dan juga sebaliknya. Shock perubahan pertumbuhan ekonomi Amerika Serikat dan China awal periode sampai akhir periode di respon fluktuatif oleh perubahan pertumbuhan ekonomi Indonesia.

Shock perubahan pertumbuhan ekonomi Amerika Serikat direspon tinggi oleh perubahan pertumbuhan ekonomi Indonesia periode awal, namun menurun pada periode keempat. Hal ini karena imbas krisis keuangan yang bersumber dari Amerika Serikat. Tanggal 9 Agustus 2007, BNP Paribas Prancis menyatakan ketidaksanggupannya untuk mencairkan sekuritas yang terkait dengan subprime mortgage dari AS. Pernyataan tersebut merupakan sumber awal terjadinya krisis keuangan yang selanjutnya meluar dan menjadi krisis likuiditas terburuk di berbagai belahan dunia. Subprime mortgage merupakan istilah untuk kredit perumahan yang diberikan kepada debitor dengan sejarah kredit yang buruk atau belum memiliki sejarah kredit sama sekali, sehingga digolongkan sebagai kredit yang berisiko tinggi. Kondisi tersebut membuat perekonomian Amerika Serikat terguncang, sehingga direspon menurun oleh perubahan pertumbuhan ekonomi Indonesia.

Shock perubahan pertumbuhan ekonomi China direspon menurun oleh perubahan pertumbuhan ekonomi Indonesia periode tiga sampai enam. Hal ini memberikan arti bahwa krisis keuangan global yang ditimbulkan oleh Amerika Serikat juga berdampak pada perlambatan pertumbuhan ekonomi China. Pengaruh krisis keuangan tersebut begitu besar dirasakan bagi pertumbuhan ekonomi China, yang semenjak tahun 1990-an mengalami pertumbuhan ekonomi dengan angka dua digit, namun krisis keuangan global membuat pertumbuhan ekonomi China dengan angka satu digit. Kondisi tersebut memberikan arti bahwa krisis keuangan global memberikan efek penularan (contagion effect) ke ekonomi China. FDI di China juga menurun selama awal krisis keuangan, tetapi pasca krisis keuangan pulih kembali hampir ke tingkat sebelum krisis. Kondisi tersebut juga memperlambat pertumbuhan ekonomi China. Oleh karena itu, respon perubahan pertumbuhan ekonomi Indonesia juga mengalami perlambatan.

Gambar 4 menunjukkan bahwa respon perubahan pertumbuhan ekonomi Indonesia fluktuatif akibat shock $\mathrm{Rp} / \mathrm{USD}$ dan Rp/RMB. Respon perubahan pertumbuhan ekonomi Indonesia masih lebih baik Amerika Serikat dibandingkan dengan China. Hal ini karena respon perubahan pertumbuhan ekonomi Indonesia akibat shock pertumbuhan ekonomi China dari awalnya positif kembudian menurun negatif sampai akhir periode, serta masih juah mendekati garis keseimbangan. Pertumbuhan ekonomi China mengalami perlambatan berawal dari krisis global pada tahun 2008. Pasca krisis global, ekobomi China bertransformasi dari berbasis ekspor menjadi berbasis investasi. Transformasi tersebut bertujuan untuk mengembalikan pertumbuhan ekonominya.

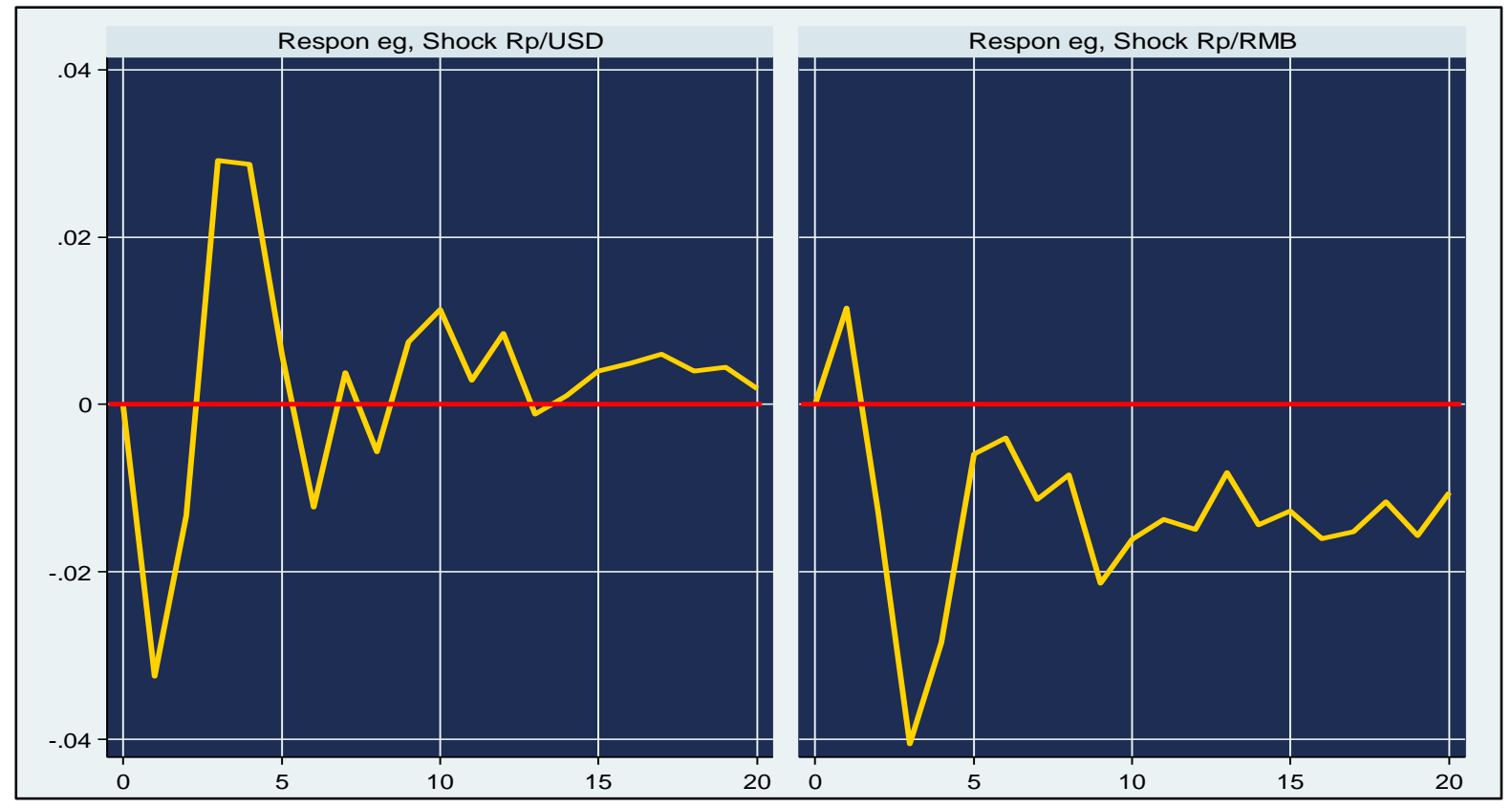

Gambar 4. Respon Pertumbuhan Ekonomi Indonesia Akibat Shock Rp/USD dan Rp/RMB 
Kebijakan bertransformasi dari berbasis ekspor menjadi berbasis investasi menyebabkan ekonomi China bergantung pada ekspansi kredit untuk menghasilkan pertumbuhan ekonomi. Investasi berlebihan di China meningkatkan hutang sehingga dapat meningkatkan risiko krisis keuangan. Oleh karena itu, pemerintah China menetapkan kebijakan rebalancing economy. Kebijakan tersebut dilakukan dengan cara mengalihkan investasi menjadi konsumsi serta perubahan sektor ekonomi dari ekonomi berbasis sektor industri menjadi ekonomi berbasis sektor jasa. Transformasi itu yang menyebabkan perlambatan ekonomi China, sehingga direspon negatif oleh perubahan pertumbuhan ekonomi Indonesia.

Gambar 5 menunjukkan bahwa shock perubahan harga minyak direspon negatif oleh perubahan pertumbuhan ekonomi Indonesia. Dalam jangka panjang juga tidak terlihat tanda-tanda pergerakan respon perubahan pertumbuhan ekonomi Indonesia menuju keseimbangan atau mendekati nol (convergence). Artinya, perubahan harga minyak tetap direspon oleh perubahan pertumbuhan ekonomi Indonesia karena efeknya yang permanen. Perubahan harga minyak di pasar intemasional pada prinsipnya mengikuti aksioma pasar, yaitu penentuan tingkat harga minyak berdasarkan mekanisme permintaan dan penawaran pasar. Hal ini yang menyebabkan perubahan harga minya dunia mengalami fluktuatif.

Energi menjadi salah satu faktor produksi output, sehingga berdampak pada pertumbuhan ekonomi. Salah satu sumber energi adalah minyak. Perubahan harga minyak akan berdampak pada peningkatan harga faktor-faktor produksi sehingga biaya produksi yang harus dikeluarkan oleh perusahaan meningkat. Hal tersebut menyebabkan perusahaan harus meningkatkan harga jual dari produknya untuk tetap menjaga keuntungaan. Peningkatan harga jual tersebut akan mendorong tingginya inflasi, sehingga daya beli masyarakat mengalami penurunan, maka direspon

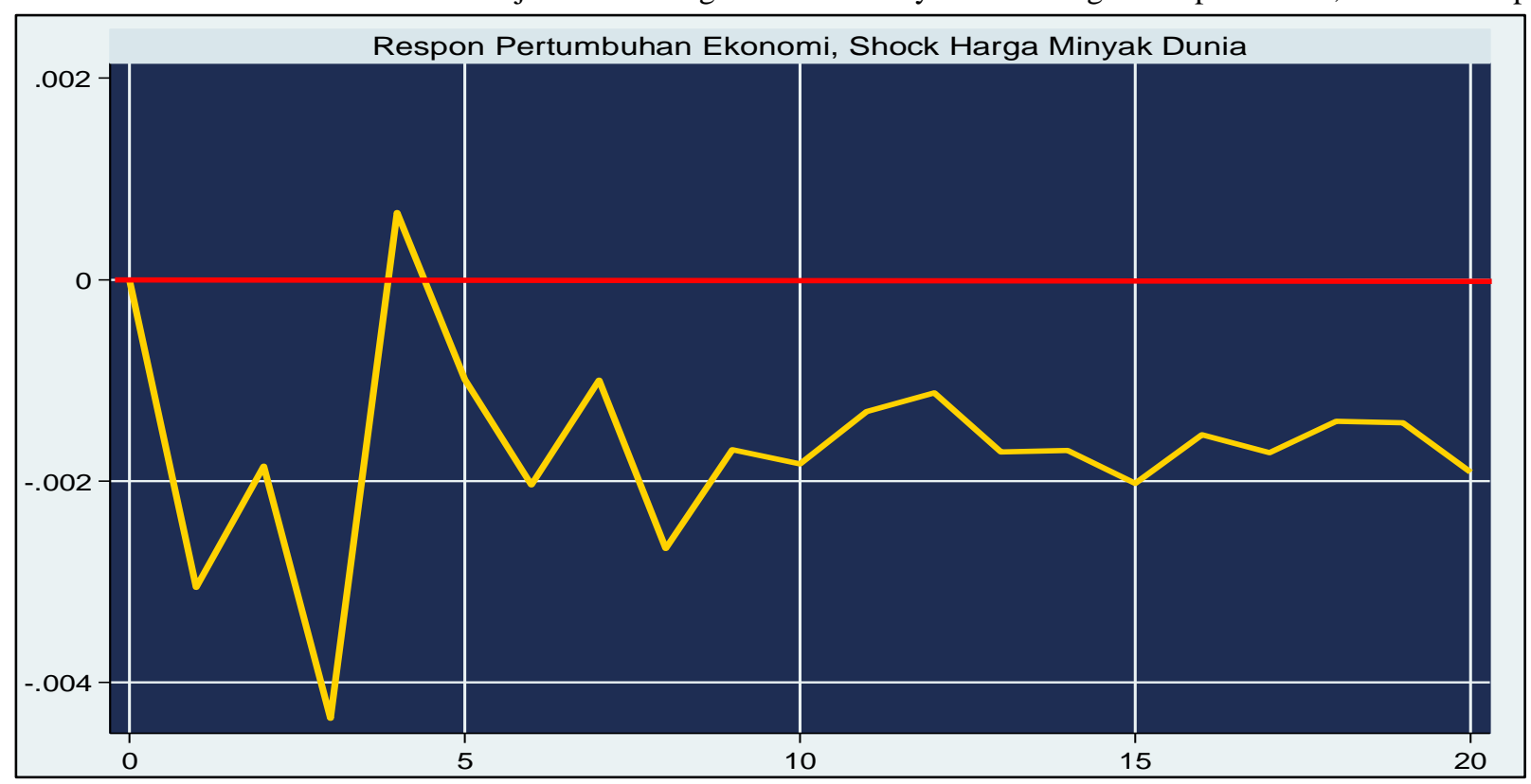

Gambar 5. Respon Pertumbuhan Ekonomi Indonesia Akibat Shock Harga Minyak Dunia

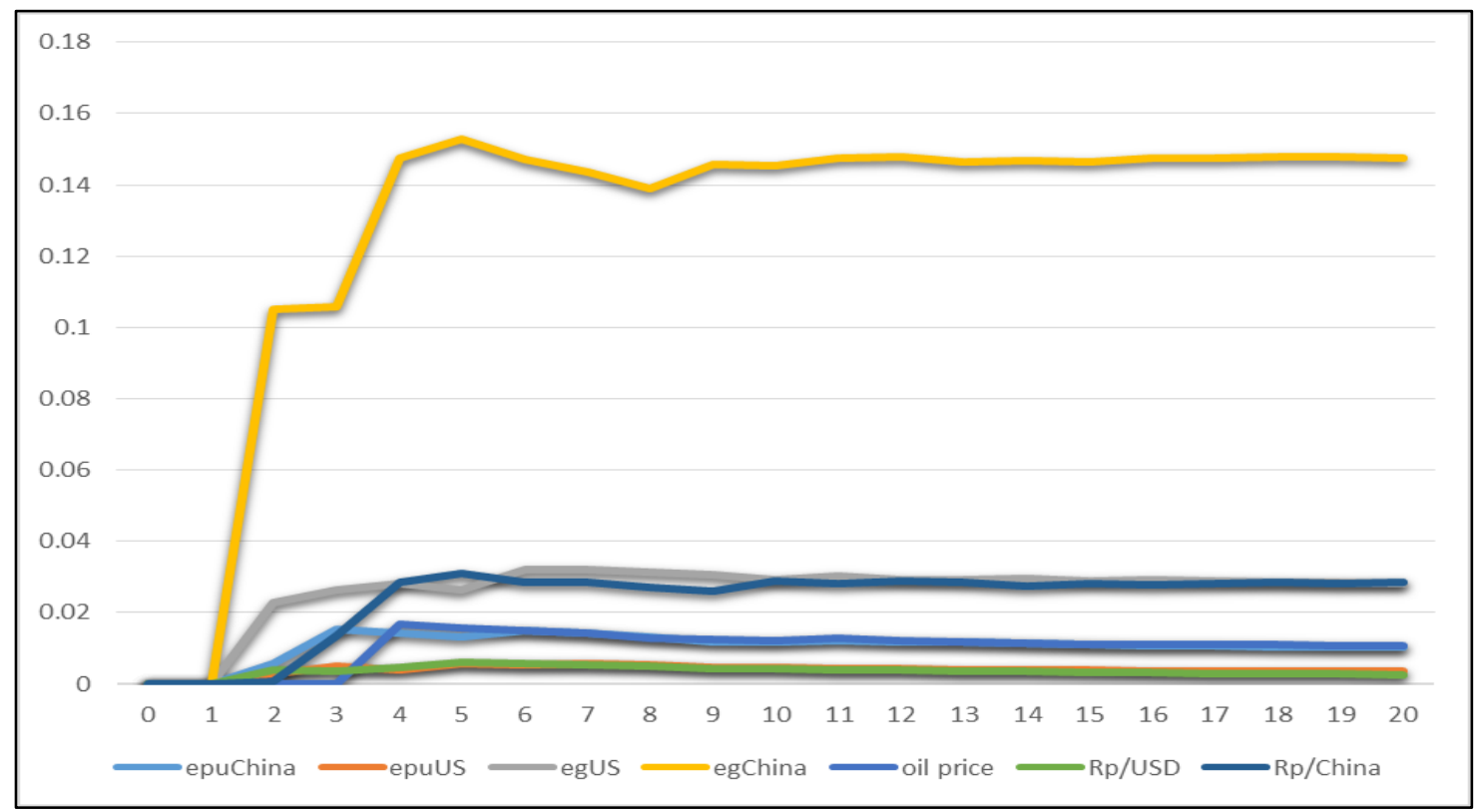

Gambar 6. Variance Decomposition Variabel Eksternal 
negatif oleh perubahan pertumbuhan ekonomi Indonesia. Pemerintah Indonesia sebagai pembuat kebijakan harus mampu memperhatikan perkembangan harga minyak dunia, mengingat pengaruh fluktuasi harga minyak sangat berbengaruh besar terhadap pertumbuhan ekonomi.

Variance decomposition menunjukkan seberapa besar kontribusi dari variabel eksternal terhadap variabel pertumbuhan ekonomi ketika terjadi shock. Kontribusi variabel eksternal paling tinggi terhadap pertumbuhan ekonomi Indonesia yaitu pertumbuhan ekonomi China, sedangkan variabel eksternal lainnya kontribusinya relatif sama. Hal ini menjadi temuan bahwa pertumbuhan ekonomi China lebih berperan dalam mempengaruhi kinerja pertumbuhan ekonomi Indonesia, sehingga melampaui pertumbuhan ekonomi Amerika Serikat.

Cukup besarnya kontribusi yang ditimbulkan oleh shock perubahan pertumbuhan ekonomi China terhadap perubahan pertumbuhan ekonomi Indonesia dikarenakan ukuran perekonomian China yang besar. Peran China terhadap pertumbuhan ekonomi Indonesia dapat melalui perdagangan internasional, sebab China adalah mitra dagang utama yang memberi kontribusi besar kepada Indonesia. Ada beberapa faktor yang membuat Cina berkontribusi cukup tinggi, yakni efek perang dagang masih kecil ke kinerja ekonomi Cina karena proses rebalancing dengan penguatan konsumsi domestik terbukti berhasil. Faktor lainnya yaitu Bank Sentral Cina memotong syarat minimum kecukupan modal bank yang menyalurkan kredit konsumsi sebesar 1\%, sehingga hal ini mendorong penyaluran kredit domestik semakin meningkat. Kebijakan tersebut membuat pertumbuhan ekonomi China tumuh positif, maka berdampak pada pertumbuhan ekonomi Indonesia.

\section{Simpulan dan Implikasi Penelitian}

Hasil estimasi VECM menunjukkan bahwa ketidakpastian kebijakan ekonomi China dan kontibusi pertumbuhan ekonomi China lebih berpengaruh besar dibandingkan Amerika Serikat terhadap pertumbuhan ekonomi Indonesia. Hal ini memberikan arti bahwa peran China ternyata lebih berpengaruh besar dibandingkan Amerika Serikat bagi perekonomian Indonesia. Pertumbuhan ekonomi China yang sangat pesat dan berkelanjutan dibandingkan dengan Amerika Serikat memiliki implikasi besar terhadap perekonomian Indonesia. Shock kurs rupiah terhadap dolar Amerika Serikat lebih baik dibandingkan dengan kurs rupiah terhadap RMB. Hal ini karena respon perubahan pertumbuhan ekonomi Indonesia akibat shock pertumbuhan ekonomi China dari awalnya positif kembudian menurun negatif sampai akhir periode, serta masih jauh mendekati garis keseimbangan.

\section{Implikasi penelitian}

Dampak China agar tidak terlalu tinggi terhadap ekonomi Indonesia, maka pemerintah perlu melakukan pembatasan Tarif dan Kuota Impor, penguatan Ekonomi Berbasis UMKM, dan pembangunan Infrastruktur. Diharapkan BI dan Pemerintah Indonesia tetap kompak dalam menjaga stabilitas kurs. Shock perubahan harga minyak direspon negatif oleh perubahan pertumbuhan ekonomi Indonesia. Dalam jangka panjang juga tidak terlihat tanda-tanda pergerakan respon perubahan pertumbuhan ekonomi Indonesia menuju keseimbangan atau mendekati nol (convergence). Pemerintah Indonesia perlu mengurangi ketergantungan terhadap komoditas minyak dan memprediksi harga minyak di masa yang akan datang secara akurat.

\section{Referensi}

Agénor, P.-R., Alper, K., \& Pereira da Silva, L. (2018). External Shocks, Financial Volatility and Reserve Requirements in an Open Economy. Journal of International Money and Finance, 83, 23-43. https://doi.org/10.1016/j.jimonfin.2018.01.003

Akinsola, M. O., \& Odhiambo, N. M. (2020). Asymmetric Effect of Oil Price on Economic Growth: Panel Analysis of Low-Income Oil-Importing Countries. Energy Reports, 6, 1057-1066. https://doi.org/10.1016/j.egyr.2020.04.023

Alexopoulos, M., \& Cohen, J. (2015). The Power of Print: Uncertainty Shocks, Markets, and the Economy. International Review of Economics and Finance, 40, 8-28.

Allegret, J. P., \& Benkhodja, M. T. (2015). External Shocks and Monetary Policy in an Oil Exporting Economy (algeria). Journal of Policy Modeling, $37(4)$, 652-667. https://doi.org/10.1016/j.jpolmod.2015.03.017

Anggraini, D. R., \& Permatasari, B. (2020). Pengaruh Nilai Tukar Dolar Dan Inflasi Terhadap Perekonomian Indonesia. REVENUE: Jurnal Manajemen Bisnis Islam, 1(2), 147-158.

Artami, R. J., \& Hara, Y. (2018). The Asymmetric Effects of Oil Price Changes on the Economic Activities in Indonesia. Signifikan: Jurnal Ilmu Ekonomi, 7(1), 59-76.

Bhagat, S., Ghosh, P., \& Rangan, S. P. (2013). Economic Policy Uncertainty and Economic Growth in India. Indian Institute of Management Bangalore Working Paper No: 407.

Dungey, M., \& Vehbi, T. (2015). The Influences of International Output Shocks from the Us and China on Asean Economies. Journal of Asian Economics, 39 , https://doi.org/10.1016/j.asieco.2015.05.003

$59-71$.

Dutu, R. (2016). Why Has Economic Growth Slowed down in Indonesia? An Investigation into the Indonesian Business Cycle Using an Estimated Dsge Model. Journal of Asian Economics, 45, 4655. https://doi.org/10.1016/j.asieco.2016.06.003

Gylych, J., Jbrin, A. A., Celik, B., \& Isik, A. (2020). The Effect of Oil Price Fluctuation on the Economy of Nigeria. International Journal of Energy Economics and Policy, 10(5), 461-468.

Haseeb, M., Kot, S., Iqbal Hussain, H., \& Kamarudin, F. (2021). The Natural Resources Curse-Economic Growth Hypotheses: Quantile-on-Quantile Evidence from Top Asian Economies. Journal of Cleaner Production, 279, 123596. https://doi.org/10.1016/j.jclepro.2020.123596

Irsania, P., \& Noveria, A. (2014). Determinan Pertumbuhan Ekonomi di Indonesia periode 19832012. Jurnal Studi Ekonomi Pembangunan, 5(3), 17-32. 
Istiak, K., \& Serletis, A. (2018). Economic Policy Uncertainty and Real Output: Evidence from the G7 Countries. Applied Economics, 1-31.

Kala, G., Masbar, R., \& Syahnur, S. (2018). The Effect of Exchange Rate, Inflation, Capital and Labor Force on Economic Growth in Indonesia. Jurnal Ekonomi Dan Kebijakan Publik Indonesia, 5(1), 35-50.

Liu, H., Liu, Y., \& Wang, Y. (2020). Exploring the Influence of Economic Policy Uncertainty on the Relationship Between Tourism and Economic Growth with an Mf-Var Model. Tourism Economics, $X X(\mathrm{X}), 1-20$.

Lütkepohl, H. (2005). New Introduction to Multiple Time Series Analysis. Springer.

Majidli, F., \& Guliyev, H. (2020). How Oil Price and Exchange Rate Affect Non-oil GDP of the Oil-rich Country - Azerbaijan? International Journal of Energy Economics and Policy, 10(5), 123-130.
Murtala, Masbar, R., \& Nasir, M. (2017). Fluctuation Analysis of Rupiah Exchange Rate of Dollar United States in Indonesia. European Journal of Agriculture and Forestry Research, 5(6), 37-50.

Nizar, M. A. (2012). Dampak Fluktuasi Harga Minyak Dunia Terhadap Perekonomian Indonesia. Buletin Ilmiah Litbang Perdagangan, 6(2), 189-210.

Purba, J. H. V., \& Magdalena, A. (2017). Pengaruh Nilai Tukar Terhadap Ekspor Dan Dampaknya Terhadap Pertumbuhan Ekonomi Indonesia. DeReMa Jurnal Manajemen, 12(2), 285-295.

Ramana, F., \& Nasrudin. (2018). Dampak Devaluasi Yuan Terhadap Perekonomian Indonesia Pendekatan Model Persamaan Simultan. Buletin Ilmiah Litbang Perdagangan, 2(1), 117-134.

Sahinoz, S., \& Cosar, E. E. (2018). Economic policy uncertainty and economic activity in Turkey. Applied Economics Letters, 1-5. 